Please share your stories about how Open Access to this article benefits you.

\title{
The Future of the US Research University
}

\author{
by David Shulenburger
}

2011

This is the published version of the article, made available with the permission of the publisher. The original published version can be found at the link below.

Shulenburger, David. (Feb. 2011) "The Future of U.S. Research Universities” Research Library Issues, no. 274.

Published version: http://publications.arl.org/rli274

Terms of Use: http://www2.ku.edu/ scholar/docs/license.shtml 


\title{
The Future of the \\ US Research University
}

\author{
David Shulenburger, Senior Fellow, \\ Association of Public and Land-Grant Universities
}

Introductory Note: Dr. Shulenburger's presentation was originally delivered at the Association of Research Libraries' Annual Meeting in Washington, DC on October 14, 2010. To listen to audio from this presentation and access additional information, please visit http://www.arl.org/resources/pubs/mmproceedings/157mm-proceedings.shtml.

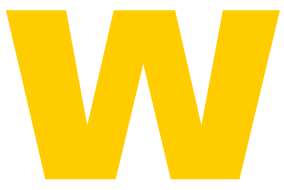

hen US higher education receives the accolade of best in the world, the universities referenced are our research universities. Jonathan Cole's excellent volume The Great American University 1 is largely devoted to this set of institutions.

The titles of three of Cole's chapters capture in a few words the expansive nature of US research university achievements. The first, It began with a Fly: Genetics, Genomics and Medical Research, takes us to dozens of universities from which basic discoveries led to treatments in use today to preserve, prolong, and enhance human, animal, and plant life. Buckeyballs, Bar Codes, and the GPS: Our Origins, Our Planet, Our Security and Safety, examines the nature of matter and the key steps of discovery that led to products like the computer and the Internet. The third chapter, Nosce te Ipsum: Culture, Society and Values, takes the reader into the arts, humanities, and social sciences developments without which the word "university" would have far less meaning.

Without these universities, the millions they have educated and the research developments that flowed from them, life today would be far less productive, far less rewarding, far more mysterious, and far shorter. They operate in an open environment characterized by frequent interchange of personnel and ready sharing of research findings. In a large sense, US research universities constitute a single ecosystem. 
Given the interdependence among these great institutions, both private and public, one must speculate about the subjunctive. Were a few of these great universities so weakened at some point that they could not support research, would their extraordinary chain of research developments have been broken? What might not have been discovered or invented that is key in today's civilization? The probability that progress would have been interrupted or derailed is, of course, far greater if the whole set of universities had been weakened.

Are these subjunctive musings becoming reality? For example, the Schumpeter column in the September 4, 2010 issue of The Economist acknowledges the "best in the world" status of US higher education but concludes, "America's universities lost their way badly in the era of easy money. If they do not find it again, they may go the way of GM." Such warnings are frequent in the popular press and recent monographs.

What I give you today is my analysis as an economist of the dangers facing the ecosystem of research universities. My analysis focuses on research universities only.

A central characteristic of research universities is that they thrive on synergy that flows from their mixture of research, graduate study, and undergraduate instruction. Each element depends on the other and each is improved by the presence of the others. Undergraduate instruction is improved by the depth of faculty expertise and the

Research universities...thrive on synergy that flows from their mixture of research, graduate study, and undergraduate instruction. wealth of library, computing, and laboratory resources available. Graduate study is strengthened by the opportunities to participate in cutting edge research and to learn the craft of teaching in a rich, supportive environment. Faculty expertise is present

because resources that flow from tuition, state appropriations, endowment funding, and research grants and contracts enable these universities to acquire the resources needed to house and support their programs of research.

Forces that threaten to weaken this synergy are growing stronger. Even if it were possible to provide undergraduate education with the same qualities, to equally well educate graduate students and to conduct the same level of cutting edge research in single-mission institutions, the financial interdependence of the three activities makes it unlikely that institutions attempting to do so could thrive. 
What are the factors that threaten to undercut this synergy?

1. Undergraduate education in the United States is increasingly being undertaken by students in non-research universities and colleges.

Between 1970 and 2008 the proportion of undergraduates studying at research universities declined from 29 percent to 18 percent, while the proportion studying at two-year colleges increased from 27 percent to 36 percent. At for-profit institutions the increase was from essentially zero at the beginning of the period to 12 percent today. Because freshman/sophomore education subsidizes junior/senior instruction, and undergraduate instruction indirectly subsidizes graduate instruction, the shift of undergraduates from research universities to community colleges, regional universities, and for-profit universities ensures that the implicit subsidy for research universities will grow at a slower rate than the US undergraduate population.

2. State subsidy of research universities is dropping. In 1987, roughly $\$ 11,600$ was appropriated per FTE student in 2009 constant dollars. By 2009, appropriations were down to $\$ 9,700$, a decline of approximately $\$ 1,900$ per student. State appropriations are intended primarily to support undergraduate education but they also permit employment of researchcapable faculty, build research libraries and specialized computing structures, etc.

3. Externally funded research increasingly does not pay for itself. Institutional expenditure for research has increased from 11.6 percent of total university research expenditures in 1972 to 20.1 percent in 2008. Much of this increased university subsidy of research is the direct result of the federal government's reduction in the proportion of facilities and administrative research costs its grants reimburse.

4. At both public and private universities, endowment levels fell sharply after fall 2008 and remain below fall 2008 levels today. Many prudent endowment managers have reduced their annual payout because of the increased uncertainty of future returns.

In the meantime, other financially unimpaired vendors, i.e., federal labs, contract research firms, and for-profit firms, are willing to conduct federally 
funded research. Other vendors, community colleges, regional universities, and for-profits are willing to provide undergraduate education. The for-profit providers, by the way, are major providers of professional graduate education, leaving only disciplinary graduate education without an alternate provider.

What are the possibilities for changing the funding picture and nourishing the synergy research universities require?

Can tuition be increased enough to replace lost state and endowment support? Perhaps. Tuition has increased at more than double the rate of inflation for over 20 years, but the queues for admissions to research universities grow longer and the proportion admitted declines over time. In competitive markets, prices, i.e., tuition, would increase at an even faster rate and/or many new competitors would enter the market until some equilibrium was reached, but rates of increase in tuition have been slowed by three forces:

1. University presidents share the fear that higher education will become a luxury good for only the privileged if tuition becomes so high that others are excluded.

2. State governments have a role in appointing governing boards that control tuition and/or they directly or indirectly control tuition.

3. The threat of federal government-legislated control of tuition is continually in the air. The federal government's role as provider of Pell Grants and originator of student loans makes the federal imprimatur a must for university survival.

Tuition increases at public universities at a rate just sufficient to offset the loss of state-appropriated support leave public university educational budgets per student in real terms only slightly above their level of 20 years ago. Tuition at less constrained private research universities has grown to roughly four times that at the publics. Their disproportionate tuition increases have increased their real per student budgets to several times the size of those in public research universities. But more recently, the additional revenue from tuition increases at private research universities has been offset by the increases in financial aid needed to keep their net tuition at affordable levels.

The market response to higher tuition has been a rapid influx of for-profit universities. These firms tend to price themselves between public and private not-for-profit universities. Their enrollment growth has been exponential and 
profit growth has followed. Despite the new option presented by for-profits to students, applications for admission at prestigious public and private not-forprofit research universities have continued to grow. Can tuition at research universities continue to climb at present rates without this new for-profit competition or competition from liberal arts colleges, regional universities, and community colleges siphoning away students?

The conventional answer has been that the prestige and value of a research university education was worth the price differential. That is, for-profit, liberal arts college, regional university, or community college higher education was not really a substitute for research university higher education. Is that true now? If so, will it continue to be in the future?

Some research into earnings suggests that equally bright students from similar socioeconomic backgrounds will have roughly the same annual earnings over their lifetimes regardless of where they get their bachelor's degrees. It may be a myth that rubbing shoulders with the children of the prosperous leads to contacts that makes one prosperous throughout life. But enough students hang onto that conventional wisdom to permit private not-for-profit universities to charge a tuition differential over publics and for public research universities to charge a tuition differential over public regionals. Of course, each maintains a tuition differential over community colleges.

But what happens if this conventional wisdom is confronted with actual data on earnings of graduates, specific to university and degree? Such data might emerge from the trauma created by the for-profits. The Education Department is attempting to put in place an earnings test for graduates, measuring whether the income each institution's graduates earn is sufficient to enable them to pay off student loans. Earnings of program completers would be tracked using an existing federal database, probably the Social Security database. This is referred to in the press as the "gainful employment" test.

For now, this proposed requirement would apply only to non-degree programs, but such regulations applied to one segment of higher education tend in the longer run to be applied to all segments. This raises the specter that brands and prestige might be confronted by hard data on earnings with the result that those brands may be devalued. If the demand for education effectively becomes more price-elastic, the ability of research universities to charge higher tuitions to finance their higher cost levels will be severely weakened. 
My larger point is this: there is some limit beyond which increased tuition levels produce financial gains for research universities.

I have been around higher education too long to believe that earnings are the only measure of value. Truly educated individuals live longer, stay healthier, keep out of jail, raise more successful children, and, by most measures, live happier lives. But individual universities currently do not provide multi-faceted data that substantiates the difference that their institution makes in the lives of their graduates. Unless they begin to measure such outcomes and share that data with students, their ability to charge the premium tuition needed to fund high-cost education may well be compromised and with it may go the ability of the research university to thrive.

Perhaps we can persuade the states to return to public research universities the real per student state appropriations of 20 years ago. The same considerations apply here as apply to the tuition/earnings calculus for students. States from coast to coast are differentially funneling appropriations toward community colleges since they appear to offer lower cost education per student. This is a false economy when examined from the cost-per-degree perspective. Retention in community college is so poor that their cost to produce an associate's degree is approximately the same as the cost of producing a bachelor's degree at a four-year public university.

Note that few employers protest redeployment of state funding from research universities to other sectors of higher education. The highly educated workers they need are highly mobile and move to wherever jobs are. This is particularly true in a loose labor market.

These days, even very sophisticated work itself moves via the Internet to employers. Thus employers can rely on workers educated and located in other states or nations. Employers, at least in the short run, can enjoy lower state taxes without jeopardizing their access to the high level labor force their businesses require.

Likewise, innovation needed to keep a state's economy growing can be imported. Chilean grape growers seem to get the bulk of their innovation from research conducted at US universities. States seem to have learned that they can economize on higher education expenditure, particularly research education expenditure, without quashing innovation in their states.

If this is true for undergraduate and professional level workers and their products, it is even truer for doctoral graduates. Faculty members are among 
the most mobile of commodities. Accordingly, few states make funding of doctoral programs a priority.

But what is true for any one state is not true for the states collectively. If all states economize on research university expenditures, there will not be enough high level professionals produced, graduate educators will become scarce, and innovation will suffer.

Having the locus of responsibility for funding research universities at the state level worked well in 1862 when the Morrill Act was signed into law by President Lincoln. Transportation was poor and communication was slow and expensive. At that time, if a state wanted the benefits brought by a research university, it had to invest in building and maintaining one within its own borders.

Federalism devolved the responsibility for higher education to the states at this time, an appropriate decision. But today's high speed transmission of information and high mobility of people and capital make the state locus of responsibility for funding research universities quite problematic.

How does one convince states to behave in a manner that is responsive to the good of the whole nation? How do you convince them not to be free-riders? This question is critical because the states still supply 50 percent of the funding for educational programs at research universities.

That the federal government understands this problem is evident in the requirement that Congress embedded in the stimulus funding package that states maintain their higher education funding effort at least at the 2006 level in order to qualify for the education portion of these funds. Similar maintenanceof-effort provisions are embedded in other legislation.

But the downward course taken by state higher education appropriations over time demonstrates that such requirements have not stemmed state disinvestment.

Perhaps some state will find that funding research universities better will pay dividends for its citizens. Universities ought to be building this case and supplying data to demonstrate how past investments have paid off.

While we must not give up on the efforts to restore state funding, I am not optimistic that such efforts will succeed in time to avert further serious damage. It is time for the larger collective, the United States, to step forward and assume more of the responsibility for research university funding.

I note that other countries have come to the understanding that research 
universities have to have significant national support. China is making major investments in its universities. I have visited some of the campuses that have received this national funding largess and am amazed how rapidly they have become substantial research universities. India is in the early stages of a similar program of massive investment. These countries are not depending on provincial government support to maintain their critical national research university needs.

In only a decade the United States has fallen from the top few countries in the world in the proportion of its 25- to 34-year-old citizens with a higher education to a tie for 11th. Tertiary attainment decline is the leading edge of the problem. Competitiveness decline is the next consequence, a consequence we can avoid if a program of targeted federal investment in research universities is begun soon.

Graduate education requires an infusion of federal funding. No state will ever utilize all the Ph.D. classicists or geologists that a single program at a single large research university can produce. States doing the calculus that compares state benefit to state cost on a program-by-program basis are likely to cease funding graduate programs that are critical to the health of the research university ecology. Only federal funding is likely to ensure adequate production of such specialists.

A general federal subsidy may be required to help research universities emerge from the funding trough into which they have fallen, not just in the last two years but in the last twenty-two years. Facilities have deteriorated, equipment is out of date, and most operations are understaffed. Research universities have gone far past economizing and are into cannibalism. Reversing this trend will take time and money.

Clearly, equity demands that the federal government quit skimping on facilities and administration cost reimbursements. The federal government must assume the full cost of federally funded research and cease relying on universities to subsidize that research.

I do not believe that research universities are in immediate danger, but danger lies ahead if we do not heed the ample warning signals. The universities themselves understand the danger and are experimenting with methods of instruction that may improve student learning outcomes at reduced cost and are otherwise streamlining operations as they cut budgets.

Research universities are weakened now but have much of their core 
strength remaining. Timely and carefully targeted investment can make the difference between losing a national strategic asset and retaining it. Stabilization of state funding and an appropriate infusion of federal funding can keep research universities strong. Absent these steps, tuition at public research universities will continue its rapid rate of increase and will someday approach the levels of private research universities. Dramatically increased tuition without the additional resources that permit dramatic increases in financial aid, of course, has ominous implications for access for low income students.

What does this mean for research university libraries? To the extent that public research universities fail to maintain their status as research universities, relatively less investment in them can be justified. Their support and derivative units, including libraries and information technology departments, are at risk of being severely reduced or even contracted out.

As funding becomes scarcer, money will be targeted to those units that can demonstrate that they promote the ultimate ends of the university, learning and research. Clearly, research university libraries must begin to demonstrate how the resources and services that they offer directly affect student learning, retention, graduation, time-to-degree, faculty research and success in winning competitive research grants. I can make the same "must" statement about student affairs, information technology, residence halls, etc.

Research university libraries can help turn the tide in funding. By making highly visible to the community the research and creative activity produced by faculty and staff, libraries can provide a major reason for state investment to increase and for private donors to increase their contributions. Libraries can provide the vehicle through which the citizenry

Libraries can play an important role in highlighting the returns that are possible when the federal government invests in research or research infrastructure at their universities. comes to understand that research universities have tangible meaning for them. Libraries can play an important role in highlighting the returns that are possible when the federal government invests in research or research infrastructure at their

universities. Properly deployed and marketed, the digital archives most of you are building can become very attractive showcases in which to display the unique contributions universities make. Of course, here I am referring to the imperative for research universities to engage in the distribution of research, a topic about which much has been said.

Clearly, research universities, public and private, and their libraries are in the 
same boat. They thrive or decline together. The powerful information gathering, categorizing, and disseminating abilities that you command can be of great assistance in motivating needed investment. I conclude by asking you to take on one additional task: use those abilities to help your universities in their quest to maintain and grow state and federal funding and private giving. Without such growth, the synergy of the undergraduate, graduate, and research environment cannot be nurtured and if it is not, the role of research university libraries will inevitably shrink.

Without the set of research university accomplishments Jonathan Cole describes in The Great American University, life today would be far less productive, far less rewarding, far more mysterious, and far shorter. I am optimistic that we as a society will realize the enormous cost of letting our research universities deteriorate and will take the actions required to preserve and strengthen these great institutions.

1 Jonathan R. Cole, The Great American University: Its Rise to Preeminence, Its Indispensable National Role, Why It Must Be Protected, (New York: Public Affairs, 2009).

(C) 2011 David Shulenburger

This article is licensed under a Creative Commons Attribution-NoncommercialShare Alike 3.0 United States License. To view a copy of this license, visit http: / / creativecommons.org/licenses/by-nc-sa/3.0/us/.

To cite this article: David Shulenburger. "The Future of the US Research University." Research Library Issues: A Bimonthly Report from ARL, CNI, and SPARC, no. 274 (February 2011): 1-10.

http: / / www.arl.org/resources/pubs/rli/archive/rli274.shtml. 